\title{
Digital Branding in Increasing Civic Engagement; A Public Relation Strategy in the Battle of Perceptions
}

\author{
Akmal Mundiri ${ }^{1 *}$, Hasan Baharun ${ }^{2}$, Abd Hamid Wahid ${ }^{2}$, Zamroni ${ }^{3}$, Khoiriyah \\ Ramadhani $^{2}$, Latifatul Imamah ${ }^{2}$, and Ummi Zakiyah ${ }^{2}$
}

\author{
${ }^{I}$ IAIN Pekalongan, Central Java, Indonesia, \\ ${ }^{2}$ Nurul Jadid University, Paiton, Probolinggo, East Java, Indonesia \\ ${ }^{3}$ IAIN Samarinda, Borneo, Indonesia \\ *Corresponding author.Email: akmalmundiri@gmail.com
}

\begin{abstract}
This paper aims to analyze digital branding in increasing community involvement in the Nurul Jadid Paiton Islamic boarding school, Probolinggo, East Java, Indonesia. This study uses a qualitative approach to seek more in-depth information to form a brand image strategy to foster public image and trust. To collect the research data, the researcher used interview, observation, and documentation techniques. The data that will collect in this study are related to digital branding and public relations strategies in increasing public participation. The results of research carried out by islamic boarding school public relations with several strategies to introduce the brand through a website to build digital branding to increase community interaction.
\end{abstract}

Keywords: digital branding, public relation, information system

\section{INTRODUCTION}

Islamic boarding school and society have a very close relationship in achieving goals education effectively and efficiently, but an Islamic boarding school must also support the achievement of goals or fulfill community needs. Starting from this starting point, it is necessary to regulate the relationship between Islamic boarding school and the community or public relations. Various community needs for educational activities in Islamic boarding school can be met, either directly or indirectly. The recognition of the Islamic boarding school world until now has been encouraged by the formation of a public relations organization that is running well [1].

In public relations or public relations itself, strategic plans a need that can support its performance. Public relations strategy in an effort to establish various positive relationships with the internal and external public can draw an understanding that includes the role of public relations in various activities such as informing, explaining, suggesting to persuade, invite and convince [2]. One of the public relations strategies carried out by the Islamic boarding school in the Knurl Jaded Payton Islamic Boarding School, East Java, which has the main task, namely the Islamic boarding school as a manager in building da'wah that conveyed to the public. increasingly rapid technological advances have led to various kinds of influences on life in society, one of which is in the world of Islamic boarding school. This can be seen from the dynamics of the Islamic boarding school education system, which one of the Nurul Jadid Paiton Islamic boarding schools in Probolinggo, East Java. As a boarding school that has survived until now, it is certainly inseparable from technological advances. With the advancement of technology, it can make it easier to get information to help promote Islamic boarding schools in the wider community and increase the network.

In the context of Islamic boarding school, a very strong Islamic boarding school brand will create perceptions in the minds of the public, especially prospective students and will subconsciously have a promotional impact on their respective choices [3]. The image of the Islamic boarding school needs to be introduced properly because it can be used as an asset in the process of promoting teachings and da'wah activities. It is undeniable that a systematic effort is needed to build a positive image of Islamic boarding school among the community, one of which is building a good brand. With a good brand, it will be able to provide a multiplier promotional effect on the existence of the boarding school among the community. 
Like the Nurul Jadid Islamic Boarding School, introduce its brand through websites (digital branding) such as YouTube, Instagram, and Facebook accounts. Therefore, the digital branding strategy can build the branding image of Islamic boarding school institutions, this is very important so that pesantren are easily recognized and widely known by the public. Building a positive image of the institution will create a good impression from consumers or the public that the Islamic boarding school is a superior institution.

This research focuses on digital branding in increasing community involvement in Islamic boarding schools whose public relations management is under Nurul Jadid Islamic Boarding School. In terms of the public relations management system, the facilities and digital branding strategy implemented by Nurul Jadid Islamic Boarding School are interesting studies.

\section{LITERATURE REVIEW}

The Strategy is an integrated and comprehensive frame of reference that directs choices that determine the shape and direction of an organization's activities towards achieving its goal [4].

To maintain a competitive advantage, it is necessary to have a strategy as a concept in the long term, the organization can balance its internal strengths and weaknesses with external opportunities and threats [5]. The right strategy can direct an Islamic educational organization or institution towards success to achieve its goals and still have a competitive advantage. Islamic education institutions naturally have good branding to retain customers and attract new customers to choose their institution as a place for the learning process [6].

Gender, explained that "the brandstrategy defines what the brand is supposed to achieve in terms of consumer attitude and behavior" [7]. So the brand strategy is brand management that aims to regulate all elements brand's consumer attitudes and behavior. Media as something that carries information between the source and the receiver of information [8].

In a branding strategy, we must understand the needs and desires of the students and the prospects or prospective student. A brand or brand that appears in the hearts and minds of every society and students who will register themselves in the Islamic boarding school institution. The emergence of an institutional brand channeled from community issues to society, especially for people who had lived in the lodge. For modern society, issues related to Islamic boarding schools have spread through the media, accounts, and even digital links that are consumed by the public. Digital media, especially social media, need authentic (original) stories to tell, not just marketing messages to be sent [9]. As is done by the Nurul Jadid Islamic Boarding School by introducing its brand through a website.

\section{METHODOLOGY}

The method of this research uses a qualitative approach to find more in-depth information about digital branding in building community involvement. To collect the research data, the researcher used interview, observation, and documentation techniques. The data that will collect in this research is related to digital branding, public relations strategies in increasing public participation. The data analysis technique used in this study is the Miles and Huberman data analysis technique, which consists of data reduction, data display, and conclusion drawing and verifying.

\section{RESULTS AND DISCUSSION}

The results showed that digital branding could increase community involvement in Nurul Jadid Islamic Boarding School by using several strategies carried out by public relations. Digital branding can be seen in Figure 1.

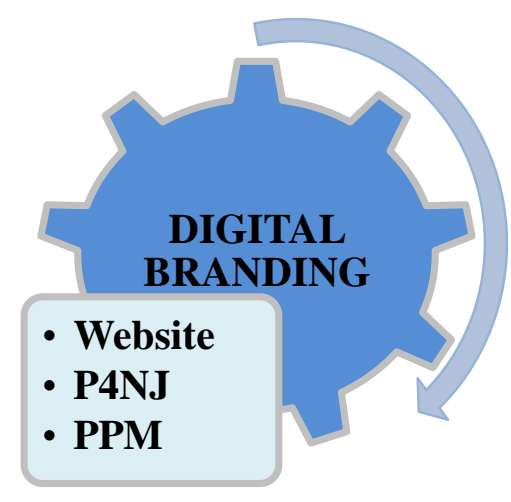

Figure 1 Digital Branding

Public relations uses a strategy by introducing the brand through the website (digital branding). And through the official pesantren account by posting various information about the Nurul Jadid Islamic boarding school, frequently used media such as Instagram, YouTube, Facebook and other. It is intended that the santri guardian can find out about the activities that are being carried out by the pesantren. The public relations aims to provide information and also has a publication task so that the public or outsiders can find out about the activities at Nurul Jadid Islamic Boarding School. 
The information media used by Nurul Jadid Islamic Boarding School specifically a digital function, from several different accounts such as Youtube, it is only used to stream several activities, one of which is the study of the yellow book which is directly reviewed by the caregiver. Then for Instagram, which is more specific to memes, such as condolences, holidays, and the achievements of students, which aim to build public interest in Nurul Jadid. All of these are the characteristics of public relations which are one of the superior values and selling points of public relations for building branding. And specifically, the website is used to post news about pesantren activities in general, including alumni activities. And including the branding of Nurul Jadid Public Relations Islamic Boarding School in collaboration with PPM (Pesantren and Community Development). PPM has now developed product works such as Shredded Fish, Frozen Food, Anchovy Sauce, Fish Siomay, Fish Nugget, Fish Samosa, etc. PMM involves the Grinting community to make products from marine resources that already exist and are mostly managed into food, this product is marketed to housing estates through retailers and opens shops located in Karanganyar Paiton. Including the boarding school branding section, which introduced the Nurul Jadid Islamic Boarding School to the general public, more specifically the center guardians through coordinated products, integrated with PPM. With the existence of these products, directly or indirectly, And public relations has marketing at NJMart (supermarkets) with specifications in the form of Koko clothes, NJ sarongs, skullcaps, etc., which are marketed through Shopee to facilitate sales that adapt to the current pandemic conditions.

In addition to collaborating with PPM public relations at Nurul Jadid Islamic Boarding School, it also has several teams that assist in carrying out the strategies that have been made, namely the P4NJ team (Assistant Management of Nurul Jadid Islamic Boarding School), P4NJ is an organization or forum for alumni of Nurul Jadid Islamic Boarding School who are active in the community. specifically by order of caregivers. P4NJ has a central $\mathrm{P} 4 \mathrm{NJ}$ structure under which it is more specific and more specific, namely P4NJ districts and cities. The task of $\mathrm{P} 4 \mathrm{NJ}$ is to coordinate, convey information then convey messages to provide educational understanding to the center guardian whose children are lodged in Nurul Jadid Islamic Boarding School. This strategy is so helpful in carrying out public relations duties, such as when PR requires coordination with the center guardian, $\mathrm{P} 4 \mathrm{NJ}$ helps directly collect and provide education and further explanation to the center guardian.

with P4NJ, PR also collaborates with alumni who become students at various universities, by forming student organizations such as in Malang, the Nurul Jadid Alumni Student Association (IMAN), Surabaya Nurul Jadid Student Family (KAMANURJA), and Jember Nurul Jadid In Campus ( NJIC). And in addition to collaborating with the existence of this organization, apart from being able to assist public relations in conveying information to the Nurul Jadid Islamic boarding school to the community, it is also so that alumni remain in contact with the Nurul Jadid Islamic boarding school.

\section{CONCLUSION}

Based on the results of the above research, it can be concluded that Public Relations can regulate good relations between pesantren and society, especially in the world of education. Public Relations is formed by the public relations organization that belongs to the pesantren. Because technological advances in the world of Islamic boarding school education form a digital branding strategy to foster public trust, this is implemented by Nurul Jadid Islamic Boarding School, which utilizes digital branding with several strategies described above to introduce its brand through a website to build digital branding for increasing community involvement.

\section{REFERENCES}

[1] S. Niyozov, N. Memon. Islamic education and Islamization: Evolution of themes, continuities and new directions. Journal of Muslim Minority Affairs, 31 (1) (2011) 5-30. DOI: https://doi.org/10.1080/13602004.20 11.556886

[2] A. T. Verčič, D. S. Ćorić. The relationship between reputation, employer branding and corporate social responsibility. Public Relations Review, 44 (4) (2018) 444-452. DOI: https://doi.org/10.1016/j.pubrev.2018 .06 .005

[3] E. Setiawan, "Pencitraan Pondok Pesantren dan Kearifan Lokal.” Makalah. Universitas Islam Bandung, 2013.

[4] G. A.Shinkle. Organizational aspirations, reference points, and goals: Building on the past and aiming for the future. Journal of management, 38 (1) (2012) 415 455. DOI: https://doi.org/10.1177/0149206311419856

[5] V. Prieto-Sandoval, C. Jaca, J. Santos, R. J. Baumgartner, M. Ormazabal. Key strategies, resources, and capabilities for implementing circular economy in industrial small and medium enterprises. Corporate Social Responsibility and Environmental Management, $26 \quad$ (6) (2019) 1473-1484. DOI: https://doi.org/10.1002/csr.1761

[6] M. Royo-Vela, K. A. McBee. Is IS Online Chatter Just Noise? An Analysis of the Islamic State Strategic Communications. International Journal of Strategic Communication, 14 (3) (2020) 179-202. DOI: https://doi.org/10.1080/1553118X.2020.1770768 
[7] J. E. Schroeder, J. Borgerson, Z. Wu. A Brand Culture Perspective on Global Brands (pp. 153-63). London: Routledge, 2016.

[8] C. Lou, S. Yuan. Influencer marketing: how message value and credibility affect consumer trust of branded content on social media. Journal of Interactive Advertising, 19 (1) (2019) 58-73. DOI: https://doi.org $/ 10.1080 / 15252019.2018 .1533501$

[9] S. Fournier, S. Srinivasan. Branding and the risk management imperative. Marketing Intelligence Review, 10 (1) (2018) 10-17. DOI: https://doi.org/10. 2478/gfkmir-2018-0002 